\title{
A multiomics comparison between endometrial cancer and serous ovarian cancer
}

\author{
Hui Zhong ${ }^{1}$, Huiyu Chen ${ }^{1}$, Huahong Qiu ${ }^{1}$, Chen Huang ${ }^{2}$, Zhihui Wu ${ }^{\text {Corresp. } 1}$ \\ ${ }^{1}$ Department of Clinical Laboratory, Fujian Provincial Maternity and Children's Hospital, Affiliated hospital of Fujian Medical University, Fuzhou, Fujian, \\ China \\ 2 Lester and Sue Smith Breast Center, Baylor College of Medicine, Houston, TX, United States \\ Corresponding Author: Zhihui Wu \\ Email address: 13799386698@139.com
}

Background. Endometrial carcinoma (EC) and serous ovarian carcinoma (OvCa) are both among the common cancer types in women. EC can be divided into two subtypes, endometroid EC and serous-like EC, with distinct histological characterizations and molecular phenotypes. There is an increasing awareness that serous-like EC resembles serous OvCa in genetic landscape, but a clear relationship between them is still lacking.

Methods. Here, we took advantage of the large-scale molecular profiling of The Cancer Genome Atlas(TCGA) to compare the two EC subtypes and serous OvCa. We used bioinformatics data analytic methods to systematically examine the somatic mutation (SM) and copy number alteration (SCNA), gene expression, pathway activities, survival gene signatures and immune infiltration. Based on these quantifiable molecular characterizations, we asked whether serous-like EC should be grouped more closely to serous OvCa, based on the context of being serous-like; or it should be grouped more closely to endometroid EC, based on the same organ origin.

Results. We found that although serous-like EC and serous OvCa share some common genotypes, including mutation and copy number alteration, they differ in molecular phenotypes such as gene expression and signaling pathway activity. Moreover, no shared prognostic gene signature was found, indicating that they use unique genes governing tumor progression. Finally, although the endometrioid EC and serous OvCa are both highly immune infiltrated, the immune cell composition in serous OvCa is mostly immune suppressive, whereas endometrioid EC has a higher level of cytotoxic immune cells. Overall, our genetic aberration and molecular phenotype characterizations indicated that serous-like EC and serous OvCa cannot be simply treated as a simple "serous" cancer type. In particular, additional attention should be paid to their unique gene activities and tumor microenvironments for novel targeted therapy development. 


\section{A Multiomics Comparison Between Endometrial}

3 Cancer and Serous Ovarian Cancer

4

Hui Zhong ${ }^{1}$, Huiyu Chen ${ }^{1}$, Huahong Qiu ${ }^{1}$, Chen Huang ${ }^{2}$, Zhihui $\mathrm{Wu}^{1}$,

${ }^{1}$ Department of Clinical Laboratory, Fujian Provincial Maternity and Children's Hospital,

8 Affiliated hospital of Fujian Medical University, Fuzhou 350001, China

$9 \quad{ }^{2}$ Lester and Sue Smith Breast Center, Baylor College of Medicine, Houston, TX 77030, USA 10

Corresponding Author:

Zhihui Wu

No. 18 Daoshan Road, 350001 Fuzhou, Fujian, P.R. of China

Email address: 13799386698@139.com

\section{Abstract}

Background. Endometrial carcinoma (EC) and serous ovarian carcinoma (OvCa) are both among the common cancer types in women. EC can be divided into two subtypes, endometroid EC and serous-like EC, with distinct histological characterizations and molecular phenotypes. There is an increasing awareness that serous-like EC resembles serous OvCa in genetic landscape, but a clear relationship between them is still lacking.

Methods. Here, we took advantage of the large-scale molecular profiling of The Cancer Genome Atlas (TCGA) to compare the two EC subtypes and serous OvCa. We used bioinformatics data analytic methods to systematically examine the somatic mutation (SM) and copy number alteration (SCNA), gene expression, pathway activities, survival gene signatures and immune infiltration. Based on these quantifiable molecular characterizations, we asked whether serouslike EC should be grouped more closely to serous OvCa, based on the context of being serouslike; or it should be grouped more closely to endometroid EC, based on the same organ origin. Results. We found that although serous-like EC and serous OvCa share some common genotypes, including mutation and copy number alteration, they differ in molecular phenotypes such as gene expression and signaling pathway activity. Moreover, no shared prognostic gene signature was found, indicating that they use unique genes governing tumor progression. Finally, although the endometrioid $\mathrm{EC}$ and serous OvCa are both highly immune infiltrated, the immune cell composition in serous $\mathrm{OvCa}$ is mostly immune suppressive, whereas endometrioid $\mathrm{EC}$ has a higher level of cytotoxic immune cells. Overall, our genetic aberration and molecular phenotype characterizations indicated that serous-like EC and serous OvCa cannot be simply treated as a simple "serous" cancer type. In particular, additional attention should be paid to their unique gene activities and tumor microenvironments for novel targeted therapy development. 
40

41

42

43

44

45

46

47

48

49

50

51

52

53

54

55

56

57

58

59

60

61

62

63

64

65

66

67

68

69

70

71

72

73

74

75

76

77

78

79

\section{Introduction}

Endometrial carcinoma (EC) and ovarian carcinoma (OvCa) are two common female cancers, accounting for $4^{\text {th }}$ and $5^{\text {th }}$-leading causes of cancer death among women in the United States (Siegel, Miller \& Jemal, 2019). EC can be divided into two subgroups, a type I endometrioid tumors and a type II serous-like tumor (Getz et al., 2013). Compared to type I EC, type II serous-like EC was characterized with a more advanced stage and worse outcome. As for ovarian cancers, high grade OvCa serous tumors account for the most cancer death (Matulonis et al., 2016). Previous studies have identified similar genetic aberrations among serous-like EC and serous OvCa (Getz et al., 2013). For examples, both serous-like EC and serous OvCa have frequent TP53 mutation, whereas type I endometroid EC does not. Also, serous-like EC and serous OvCa are both featured with chromosome instability and copy number alteration (CNA), compared to very few CNA events in type I endometroid EC. These findings suggest that they might be caused by similar oncogenic drivers and more importantly, share common molecular mechanisms for tumor progression.

In recently years, an idea in understanding and targeting cancer for treatment has been brought up that cancers need to be classified by genetic similarity rather than tissue or organ origins (Heim et al.; Margolin et al., 2014). The rationale of such classification is that, cancer types sharing similar cancer genetic drivers and progression mechanisms are more likely to be targeted using common drugs, regardless of their tissue- or organ-origin (Aggarwal, 2010). Following this rule, there is a possibility that type II serous-like EC might be classified together with serous $\mathrm{OvCa}$, instead of being classified with type I endometroid cancer. The current treatment strategies also reflect such similarities: both serous-like EC and serous OvCa are commonly treated with platinum- or taxane-based chemotherapies, although the responsiveness varies (Moxley \& McMeekin, 2010; Brasseur, Gévry \& Asselin, 2017; Cortez et al., 2018). In comparison, type I endometroid cancer is more frequently treated with adjuvant radiotherapy (Hopkins Hospital Edward Tanner et al., 2017). Also, there is not a single targeted therapy that works well for serous-like $\mathrm{EC}$ and serous $\mathrm{OvCa}$, but type I endometroid EC patients might be treated with immunotherapy (Piulats \& Matias-Guiu, 2016). This is because some endometroid EC tumors are featured with microsatellite instability (MSI) and genomic hypermutation, which can be translated into neoantigens to attract cytotoxic immune infiltration. Therefore, it is extremely useful to have a deeper understanding of serous-like EC and OvCa. In particular, whether these two cancer types are similar enough to be categorized together (bypassing the different tissue origins) and be treated by common anti-tumor drug target identification needs to be clearly defined.

The Cancer Genome Atlas (TCGA) has generated large-scale omics data for more than 32 cancer types (Wang, Jensen \& Zenklusen, 2016). The high-throughput profiling effort has led to unprecedent understanding of somatic mutation, copy number changes, gene expression and other molecular phenotypes of each tumor type. Moreover, the TCGA data also provide a unique chance to compare the genetic aberrations across different cancer types and even allow for pancancer studies. For instance, a recent study used TCGA large-scale data to compare gynecologic 
80

81

82

83

84

85

86

87

88

89

90

91

92

93

94

95

96

97

98

99

100

101

102

103

104

105

106

107

108

109

110

111

112

113

114

115

116

117

118

119

cancers and breast cancer (Berger et al., 2018). By unsupervised analyses, this study revealed that a subset of EC samples, particularly those belonging to serous-like EC, can be clustered together with $\mathrm{OvCa}$ in genetic aberration and gene expression. One potential drawback for this type of "pan-cancer" analyses, however, is that the involvement of too many cancer types might compromise the ability to distinguish some subtle yet significant differences across some specific cancer types. To our best knowledge, there has not been a study focusing on a "side-by-side" comparison of the two types of $\mathrm{EC}$ and $\mathrm{OvCa}$, which share very close cancer tissue origin and tissue development (Mullen \& Behringer, 2014; Hoadley et al., 2018a).

Here, we take advantage of the large-scale multi-omics data generated from TCGA and perform a comprehensive comparison of molecular profiles among endometroid EC $(\mathrm{N}=411)$, serous-like EC $(\mathrm{N}=115)$ and serous $\mathrm{OvCa}(\mathrm{N}=587)$ (see Table 1). We found that although serouslike EC and serous OvCa share some common genetic drivers, they differ in multiple biological processes, including pathway activity, prognostic gene signature and immune cell infiltration. We conclude that serous-like EC and serous OvCa use different molecular mechanisms to progress and therefore, targeted therapies based on gene and pathway functions should be uniquely adapted to counter each of them.

\section{Materials \& Methods}

\section{Data download}

The TCGA data were downloaded by the R package "TCGAbiolinks"(Colaprico et al., 2016), except that the pre-normalized RNA-seq (RSEM) data were downloaded from Broad GDAC Firehose (https://gdac.broadinstitute.org/). All the data were formatted as data matrices in R. The RNA-seq data were combined and re-normalized together using upper-quantile normalization (Bullard et al., 2010). For missing values of RNA expression ( $<5 \%$ of all the RNA expression matrix entries), K-nearest neighbor $(\mathrm{KNN})$ method (implemented in the "DMwR" $\mathrm{R}$ package version 0.4.1) was used to impute them.

\section{Somatic copy number alternation (SCNA) and somatic mutation (SM)}

For SCNA analysis, all the segment-level log2 ratios were plotted out as a heatmap (Fig. 1A) to reflect the genome-wide SCNA profiles for these three cancer types. To quantify the chromosome instability, we used a previously published method (Vasaikar et al., 2019) that sums up the absolute segment-level $\log 2$ ratios for all the segments located in the same chromosome arm, while the segment lengths were weighted during the summation. The arm-level SCNAs were used to reflect the chromosome instability for these three cancer types.

For the SM analysis, the genome-wide mutation burden was inferred by summing all the recorded SM events (i.e. the sum of all the mutation sites across all genes) within the TCGA Mutation Annotation Format (MAF) files, regardless the location of the SM events. This was essentially the same way used by the R package "maftools" (Mayakonda et al., 2018), and has been similarly adopted in previous studies (Rooney et al., 2015; Li et al., 2016). The most frequently mutated genes were also summarized from the MAF files. 
To check the major genetic events (i.e. "copy-number driven" vs. "mutation-driven") driving these three cancer types (Ciriello et al., 2013), we calculated the copy number alteration rates and mutation rates for the most significant oncogenic and tumor suppressor genes $(\sim 200)$ identified in the previous pan-cancer study (Ciriello et al., 2013). One-side KolmogorovSmirnov test (i.e. "greater" vs. "less") was performed to determine the genetic event dominating the given cancer type.

\section{RNA expression and Pathway activity inference}

To investigate the gene expressional similarity between any two of the three cancer types, we used sample-wise Spearman's correlation to compute the correlation coefficents between any sample pair across different tumor types. We used the tissue-specific (i.e. uterus and ovary) genes that were summarized previously (Liu et al., 2008) to detect the tissue specificity of these cancer types (Table S1). Single sample GSEA (ssGSEA) algorithm (Barbie et al., 2009) implemented in the R package "GSVA" (version 3.6) (Hanzelmann, Castelo \& Guinney, 2013) was used to summarize the overall tissue-specific gene expression and calculate the pathway activity for the hallmark pathways (Liberzon et al., 2015). One-way ANOVA was used to select variable pathways across the three cancer types (adjusted $\mathrm{p}$ value $<0.01$ ), and the Benjamini and Hochberg (BH) method (Benjamini, Yoav; Hochberg, 1995) was used to adjust the multi-testing $\mathrm{p}$ values.

\section{Survival analysis}

We used univariate Cox proportional-hazards $(\mathrm{PH})$ regression (the "coxph" function in the R package "survival", version 2.44) (Therneau, 2019) to quantify the contribution of each gene expression to survival outcome for the three cancer types. To infer the pathways that were enriched with prognostic genes, we extract the Cox $\mathrm{PH}$ regression coefficients from the models and rank them from low (worst prognostic) to high (best prognostic) and used GSEA (Subramanian et al., 2005) implemented in WebGestalt (Liao et al., 2019) to identify the KEGG pathways enriched with bad prognostic or good prognostic genes (FDR<0.01). We used log-rank test to determine the significance of association between a given gene and survival outcome. In this survival test, the samples were dichotomized to "low" and "high" expression groups based on the median expression of the gene.

\section{Immune infiltration and composition inference}

We used ESTIMATE (Yoshihara et al., 2013) to infer the overall immune and stromal infiltration and CIBERSORT (Newman et al., 2015) to infer the detailed immune composition for the three cancer types. Both of these two tools utilize the normalized RNA expression. To simplify immune cell analysis and provide a more straightforward results, we employed a similar strategy as the one used previously to combine all the NK cells and macrophages from different NK cell subtypes and macrophage subtypes (Thorsson et al., 2018). The prognostic value of CD8 $\mathrm{T}$ cells was inferred using log-rank test as described above. 
160

161

162

163

164

165

166

167

168

169

170

171

172

173

174

175

176

177

178

179

180

181

182

183

184

185

186

187

188

189

190

191

192

193

194

195

196

197

198

199

\section{Statistics}

The statistical approaches were described partially in the text and the method sessions above. For any tests that have not been covered, the between-group difference was tested by student- $t$ test, and variability among three groups was tested by one-way ANOVA. The pathway enrichment was tested by GSEA imputation. The survival association was tested by log-rank test. A $p$ value less than 0.01 (or adjusted $p$ value in multi-testing) was considered as statistically significant. All the data processing and statistical analysis were performed under the $\mathrm{R}$ computing environment (R 3.6.0).

\section{Results}

\section{Copy number alteration}

We first examined the somatic copy number alteration (SCNA), one of the major genetic events driving tumorigenesis. Consistent with previous report (Getz et al., 2013; Berger et al., 2018), we identified very similar SCNA patterns for EC and OvCa. While type I endometroid EC has few SCNA events, serous-like EC and OvCa are both featured by high SCNA profiles. They both have obvious 3q, 5p, 8q and 20 p and 20q gain and 4q, 5q and 16q loss (Fig. 1A). Type I endometroid EC samples, on the other hand, are only characterized by 1q gain and no obvious arm-level loss. We further quantified the chromosome instability from all the arm level SCNAs (method) and found that serous-like EC and serous OvCa are more similar to each other than endometroid EC (Fig. 1B).

Furthermore, we systematically compared copy number gain and loss across all the autosomes and found that for all the quantifiable chromosome arms, both gain and loss are significantly stronger in the two serous cancer types than endometroid EC (adjusted $\mathrm{p}$ value $<$ 0.05, Student's t-test Fig. 1C). Interestingly, while the two serous cancer type have similar levels of copy number gain, OvCa has even stronger copy number loss (Fig. 1C-E) than serous-like EC. Representative chromosome arms include chromosome $4 p$ and $4 q$ (adjusted $p$ value $<0.05$, Student's t-test). Chromosome 4 is enriched with tumor suppressor genes and SCNA events related with this chromosome have been linked to several types of cancer (Wang, Uzawa \& Tanzawa; Shivapurkar et al., 1999; Singh et al., 2007). Indeed, we identified multiple tumor suppressor genes encoded in chromosome 4, including CASP3, FBXW7 and TET2 that were not only show differential loss comparing serous EC to endometroid EC, but also show additional loss in serous OvCa (Fig. S1).

\section{Somatic mutation}

Next, we examined the somatic mutation (SM) profile in these three cancer types and also the SM genes. The endometroid EC displayed a higher genome-wide somatic mutation burden than serous-like EC and serous OvCa (Fig. 2A). This was expected, due to that some of endometroid EC tumors have microsatellite instability, which causes large amount of somatic mutation (Getz et al., 2013). As for gene-level SM, the frequently muted genes for serous-like 
200 EC and OvCa both include TP53, MUC16, FLG and AHNAK. Notably, except TP53, almost all 201 other mutated genes have frequencies less than $25 \%$, suggesting that these two cancer types are 202 belong to "copy number-driven" cancer (Ciriello et al., 2013). In comparison, the top mutated 203 genes in endometroid cancers have much higher frequencies, including PTEN, ARIDIA, 204 PIK3CA, PIK3R1, MUC16 and KMT2D, but not TP53 (Fig. 2B-D). The high mutation burden 205 and frequently mutated genes indicate that at least some endometroid EC tumors belong to 206 "mutation-driven" cancer (Ciriello et al., 2013).

207 To further confirm our observation, we isolated the most significant somatic mutated 208 genes identified in the previous pan-cancer study (Ciriello et al., 2013). We further compared the 209 SCNA and somatic mutation frequencies for these genes within these three cancer types (Fig. 210 2E-G). As expected, while endometroid EC has substantial number of these genes being more 211 mutated than copy-number changed, the two serous cancer types have dominantly copy-number 212 events rather than mutations $(\mathrm{P}<2.2 \mathrm{e}-16$, one-side Kolmogorov-Smirnov test).

213 Taken together, our data analysis suggests that serous-like EC and serous OvCa are 214 similar in the genotypical aberrations of SCNA and SM, whereas endometroid EC stands out as 215 an obvious different cancer type, even though endometroid EC and serous-like EC are originated 216 from the same organ.

217

218 Gene expression and pathway activity

219 We next checked the difference in gene expression among these three cancer types.

220 Unlike SCNA or SM, Serous-like EC tumors seemed to be in an intermediate status of gene 221 expression between endometroid EC and serous OvCa (Fig. 3A). A more quantitative 222 comparison using sample-wise correlation further showed that serous-like EC has modest 223 224

225

226

227

228

229

230

231

232

233

234

235

236

237

238

239 similarities to endometroid EC (mean Spearman's correlation 0.270) and serous OvCa (mean Spearman's correlation 0.297), comparing to the low similarity between the latter two (mean Spearman's correlation 0.122) (Fig. 3B). We further speculated that endometroid organ-intrinsic gene expression might be compromised in serous-like EC tumors. To this end, we examined the expression of normal uterus-specific (Fig. 3C) and ovary-specific (Fig. 3D) genes in these cancer types. Intriguingly, while endometroid EC and serous OvCa still maintain some organ-specific gene expression profile, serous-like EC seemed to lose the organ-specific gene expression (Fig. 3C-D).

To gain more biological information, we next summarized gene expression into pathway activities using single sample GSEA (ssGSEA, see method) (Barbie et al., 2009) and performed similar comparison. Figure 3E showed the variable hallmark pathways (Liberzon et al., 2015) across these three cancer types. Consistent with gene expression, serous-like OvCa has both common pathway activities to endometroid EC and serous OvCa. For instance, some immune response related pathways, such as "inflammatory response", "interferon gamma response", "complement", "IL6-JAK-STAT signaling" are all lower in two ECs than in serous OvCa (cluster 1 in Fig. 3E) (adjusted p value $<0.05$, Student's t-test). On the other hand, the serouslike EC tumors also have similar activity for some pathways to serous OvCa, especially those 
240

241

242

243

244

245

246

247

248

249

250

251

252

253

254

255

256

257

258

259

260

261

262

263

264

265

266

267

268

269

270

271

272

273

274

275

276

277

278

279

related to metabolism (cluster 2 in Fig. 3E), including "glycolysis", "oxidative phosphorylation", "fatty acid metabolism" and "xenobotic metabolism". Together, serous-like EC displays an intermediate gene expression and signaling pathway activity between the endometroid EC and serous OvCa. In particular, the similarities in pathway activity between the two ECs argues the importance of expression-level examination beyond the clustering based on genetic aberration.

\section{Survival gene signatures}

One unique advantage of cancer data analysis based on TCGA is that the patients' clinical data is available, thus allowing the association between molecular characterizations and survival outcome. We downloaded all the available survival data for these three cancer types and found that the serous OvCa has the worst survival outcome, while the endometroid EC has the best (Fig. 4A). This observation is consistent to our understanding of these three cancer types (Siegel, Miller \& Jemal, 2019) and suggests that the TCGA survival data are large enough to perform clinically related analyses.

We reasoned that if two cancer types share similar mechanisms for tumor growth, they should also have common survival signature genes, which are related to cancer progression and drug response. To this end, we compared the survival gene signature among these three cancer types. First, we performed univariate Cox proportional-hazards $(\mathrm{PH})$ regression between each gene expression and survival outcome. To summarize the genes with good or bad prognostic values, we extracted the Cox PH coefficients and used them for GSEA analysis to identify pathways that are enriched with these genes. Notably, all three cancer types have their unique signature genes being identified, and these genes are mostly classified into different pathways (Fig. 4B-D). Nonetheless, the two EC types shared several common good or bad prognostic pathways. For instance, the expression of genes related to "Aminoactyl-RNA biosynthesis" indicates bad prognosis, and immune related genes, including "Allograte rejection" indicate good prognosis for both EC cancer types (GSEA, FDR < 0.05) (Fig. 4B-C). On the other hand, the serous OvCa has unique adverse prognostic pathways, including "Endocytosis", "Focal adhesion", and cell proliferation and growth-related pathways, such as "Ras signaling pathway", "Hippo signaling pathway", "Gastric cancer" and "Glioma” (Fig. 4D). Interestingly, genes involved in "Aminoactyl-RNA biosynthesis" have generally good prognostic values for OvCa, in contrast to the EC cancers (GSEA, FDR < 0.05). Our results of "Aminoactyl-RNA biosynthesis" is consistent with a recent report that this pathway activity is only selectively upregulated and linked to tumorigenesis in some cancer types, and one of them is endometrial cancer (Zhang et al., 2018).

In terms of detailed survival signature genes, we found that most of them are unique to each of the three cancer types, while the two ECs share several common bad and good prognostic genes (Table S2). For instance, the expression PHKA1, one of the phosphorylase kinase regulatory genes (Pallen, 2003), has a bad indication of survival outcome for both ECs but not serous OvCa (Fig. 4E-G) (log-rank test, p value <0.05). Similarly, the expression of CXCR5, an important chemokine receptor involved in multiple immune cell infiltration (Murphy, 2012), 
280

281

282

283

284

285

286

287

288

289

290

291

292

293

294

295

296

297

298

299

300

301

302

303

304

305

306

307

308

309

310

311

312

313

314

315

316

317

318

319

has a good indication of survival outcome for both ECs (log-rank test, p value $<0.05$ ) but not serous OvCa (Fig. 4H-J). In summary, our survival analysis indicates a closer relationship between the two ECs, although the serous-like EC and serous OvCa share common genetic aberrations.

\section{Immune infiltration}

Finally, we examined the immune infiltration for these three cancer types. Immunotherapy holds great promise for cancer treatment, especially when conventional chemotherapy/radiotherapy and other targeted therapy fail to achieve sufficient response. The efficacy of immunotherapy largely depends on the overall immune infiltration and immune cell composition within the tumor microenvironment (Alderton \& Bordon, 2012).

We first infer the immune and stromal cell infiltration using RNA expression of previously-established signature genes (Yoshihara et al., 2013). Both the serous OvCa and endometroid EC have higher immune infiltration than serous-like EC (Fig. 5A); however, serous OvCa also has high stromal cell infiltration (Fig. 5B, adjusted p value $<0.05$, Student's t-test). Since the stromal cells can contribute to immune suppressive signals (Valkenburg, De Groot \& Pienta, 2018), there is a possibility that serous OvCa has more immune-suppressive cells than endometroid EC. We thus run CIBERSORT (Newman et al., 2015) to explore the detailed immune cell composition within the tumor microenvironment. To our expectation, compared to the other two cancer types, endometroid EC has significantly higher level of cytotoxic immune cells, including CD8 T cells and NK cells, and also Treg cells, whose function is to constrain CD8T cells in tumor (Mougiakakos et al., 2010) (adjusted p value $<0.05$, Student's t-test, Fig. 5C). In contrast, the serous OvCa has significant amounts of macrophages and monocytes, which might together form an immune-impressive tumor microenvironment.

Furthermore, we asked whether the cytotoxic CD8 T cells can contribute to the favorable patient survival. Log-rank test analysis found that the higher amount of CD8 T cell is associated with a significantly better survival in endometroid EC (Fig. D) and a better (but not significant) survival in serous-like EC (Fig. E, log-rank test, $p$ value $<0.05$ ). In contrast, CD8 T cell infiltration does not show any prognostic value for serous OvCa (Fig. 5F). This might be due to a possibility that the low amount of CD8 T cells is not sufficient to play the anti-tumor role or that there are other immune-suppressive signals to block the function of CD8 T cells.

Together, our results suggest that serous-like EC and serous OvCa have very different immune infiltration profiles. Although serous OvCa and endometroid EC both have high immune infiltration, their immune cell contents are very different from each other and therefore, the potential immunotherapeutic strategy are also likely to be different.

\section{Discussion}

\section{The multi-omics comparison of three cancer types}

Here, we performed detailed analyses based on the TCGA high throughput data to test whether the serous-like EC should be grouped together with serous OvCa into a "serous cancer"

Peer) reviewing PDF | (2019:07:39898:2:0:NEW 26 Nov 2019) 
320

321

322

323

324

325

326

327

328

329

330

331

332

333

334

335

336

337

338

339

340

341

342

343

344

345

346

347

348

349

350

351

352

353

354

355

356

357

358

359

type or should stay with the endometroid EC as a typical "endometrial cancer" type. Our findings were summarized in Table 2. Although the similarity of SCNA and SM (particularly SCNA) favors the grouping of serous-like EC and serous OvCa, the gene expression and pathway activity, survival gene signature and immune infiltration all point out obvious difference between these two cancer types. Specially, pathway activity and survival gene signature both point to a close relationship between the two ECs than between the two "serous" cancer types. For immune infiltration, the two "serous" cancer types are also very different from each other, in terms of overall immune cell abundance and immune cell composition. Although serous OvCa has high immune cell infiltration, which is similar to endometroid EC, its immune cell composition is largely dominated by immune-suppressive macrophage and monocyte. We noticed that our result about CD8 T cell and serous OvCa was different from a recent clinical study (Goode et al., 2017), whose immunohistological analyses showed that high CD8 T cell infiltration favored a better prognosis for serous OvCa. We reasoned that besides cohort difference, the techniques used in these two studies (in silico inference based on whole bulk RNA-seq vs. immunohistology focusing on epithelial components of tumor islets) might be detecting CD8 T cells located in different tissue compartments. In particular, the whole-bulk RNA-seq reflects the CD8 T cells distributed across both tumor epithelial and stromal sites. This hypothesis can be further tested by examining the association between stroma-located CD8 T cell infiltration and the clinical outcome. Our results about the discrepancy between the two serous-like cancer and the similarity between the two ECs are consistent with a recent report that the tissue-origin largely impacts the cancer type classification (Hoadley et al., 2018b).

\section{Implications for targeted therapy development}

Unlike chemotherapy and radiotherapy, the targeted therapies target cancer's specific gene mutations, copy number alterations, proteins, signaling pathways or tumor microenvironment components (Baudino, 2015). Detailed molecular profiling and comparative characterizations would be very helpful to delineate tumor groups and develop novel tumor treatment strategies (Aggarwal, 2010). For instance, the characterizations on genetic aberration have proven to be important information resources for targeted therapy development, with excellent examples including BRCA1 mutation, HER2 amplification and microsatellite instabilities (MSI) (Tung \& Garber, 2018; Havel, Chowell \& Chan, 2019; Oh \& Bang, 2019). In this regarding, serous-like EC and serous OvCa treatment can be benefited from common targeted therapies. Indeed, there have been clinical trials utilizing EGFR and HER2 amplification in these two cancer types (Wilken et al., 2012; Makker et al., 2017). Based on our analysis, we can also propose that the frequent mutation of PIK3CA (Figure 2B) could be utilized to stratify patients for PIK3CA inhibitor-based treatment. On the other hand, the gene expression, pathways activity and tumor microenvironment characterizations are also too important to neglect. We propose that the substantial differences on these molecular phenotypes are valuable to understand potential responsiveness of targeted therapy and to identify novel therapeutic opportunities. For instance, our observations on immune profiling (Fig. 5) suggest that the 
360

361

362

363

364

365

366

367

368

369

370

371

372

373

374

375

376

377

378

379

380

381

382

383

384

385

386

387

388

389

390

391

392

393

394

395

396

397

398

399

immunotherapy should be targeted to inhibit the stromal signals in serous OvCa to first increase the proportion of cytotoxic CD8 T cells or NK cells. In contrast, since there has been a large amount of CD8 T cell in the endometroid cancer, the immunotherapy for this cancer type might be focused on maximizing the function of CD8 T cells using immune checkpoint inhibitors.

\section{Limitations of this study}

Although we strived to perform an unbiased and comprehensive bioinformatic analysis to understand the genetic aberration and molecular phenotypes of endometroid EC, serous-like EC and serous $\mathrm{OvCa}$, we realized that there are several limitations that could not be readily overcome by current datasets and analysis methods. First, the TCGA clinical data do not have detailed records about different therapies (e.g. targeted therapies or clinical trials) each patient received. Therefore, we could not exclude the possibility that some survival results were impacted by the therapeutic difference, instead of intrinsic gene expression. Secondly, there are several molecular phenotypes, such as pathway activity and immune cell infiltration were inferred by in silico bioinformatic tools, rather than from experimental tests. There are some controversies and pitfalls in using these tools (Li, Liu \& Liu, 2017; Newman et al., 2017; Schubert et al., 2018), although they have all been confirmed by experimental benchmarked when they were originally published (Hemminki et al., 1998; Hanzelmann, Castelo \& Guinney, 2013; Yoshihara et al., 2013; Newman et al., 2017). Lastly, we want to note that there might be potential batch effects for the gene expression datasets profiled across different cohorts. Although there are several tools designed to adjust batch effect (Oytam et al., 2016; Leek et al., 2018), it is very difficult to remove batch effect without affecting the true biological signals (Nygaard, Rødland \& Hovig, 2016; Goh, Wang \& Wong, 2017; Newman et al., 2017). For this consideration, we chose to perform re-normalization across the different cohorts rather than the explicit batch effect correction. Our strategy was similar to several pan-cancer studies (Rooney et al., 2015; Berger et al., 2018; Ge et al., 2018; Rosario et al., 2018). We would foresee that with better clinically annotated cohorts, more advanced experimental techniques, such as single-cell multi-omics techniques and more sophisticated data processing methods, these analyses would be largely improved.

\section{Conclusions}

In summary, our analysis identifies both similarities and discrepancies between serouslike $\mathrm{EC}$ and serous $\mathrm{OvCa}$ and provides possible clinical contextualization for some of the characterizations. On the genetic profiles, serous-like EC and serous OvCa share very similar SCNA and SM profiles, which was the main reason that they were recently considered to be a uniformed "serous" cancer type. However, there are several important molecular phenotype differences, including gene expression and pathway activity, survival signature genes and immune infiltration. Our analysis indicates that common targeted therapies might be developed to treat serous-like EC and serous OvCa based on mutation drivers, such as PIK3CA. Equal amount of considerations, if not more, should be paid to on the gene expression, signal pathway 
400

401

402

403

404

405

406

407

408

409

410

411

412

413

414

415

416

417

418

419

420

421

422

423

424

425

426

427

428

429

430

431

432

433

434

435

436

437

438

439

440

441

442

443

444

activities and tumor microenvironment to investigate drug responsiveness and to identify novel molecular targets for them individually.

\section{References}

Aggarwal S. 2010. Targeted cancer therapies. Nature Reviews Drug Discovery. DOI: $10.1038 / \mathrm{nrd} 3186$.

Alderton GK, Bordon Y. 2012. Tumour immunotherapy-leukocytes take up the fight. Nature Reviews Immunology. DOI: 10.1038/nri3197.

Barbie DA, Tamayo P, Boehm JS, Kim SY, Moody SE, Dunn IF, Schinzel AC, Sandy P, Meylan E, Scholl C, Fröhling S, Chan EM, Sos ML, Michel K, Mermel C, Silver SJ, Weir BA, Reiling JH, Sheng Q, Gupta PB, Wadlow RC, Le H, Hoersch S, Wittner BS, Ramaswamy S, Livingston DM, Sabatini DM, Meyerson M, Thomas RK, Lander ES, Mesirov JP, Root DE, Gilliland DG, Jacks T, Hahn WC. 2009. Systematic RNA interference reveals that oncogenic KRAS-driven cancers require TBK1. Nature. DOI: 10.1038/nature08460.

Baudino TA. 2015. Targeted Cancer Therapy: The Next Generation of Cancer Treatment. Current drug discovery technologies 12:3-20.

Benjamini, Yoav; Hochberg Y. 1995. Controlling the False Discovery Rate - a Practical and Powerful Approach to Multiple Testing. Journal of the Royal Statistical Society Series BMethodological 1995.pdf. Journal of the Royal Statistical Society Series B (Methological). DOI: $10.2307 / 2346101$.

Berger AC, Korkut A, Kanchi RS, Hegde AM, Lenoir W, Liu W, Liu Y, Fan H, Shen H, Ravikumar V, Rao A, Schultz A, Li X, Sumazin P, Williams C, Mestdagh P, Gunaratne PH, Yau C, Bowlby R, Robertson AG, Tiezzi DG, Wang C, Cherniack AD, Godwin AK, Kuderer NM, Rader JS, Zuna RE, Sood AK, Lazar AJ, Ojesina AI, Adebamowo C, Adebamowo SN, Baggerly KA, Chen T-W, Chiu H-S, Lefever S, Liu L, MacKenzie K, Orsulic S, Roszik J, Shelley CS, Song Q, Vellano CP, Wentzensen N, Cancer Genome Atlas Research Network, Weinstein JN, Mills GB, Levine DA, Akbani R. 2018. A Comprehensive Pan-Cancer Molecular Study of Gynecologic and Breast Cancers. Cancer cell 33:690-705.e9. DOI: 10.1016/j.ccell.2018.03.014.

Brasseur K, Gévry N, Asselin E. 2017. Chemoresistance and targeted therapies in ovarian and endometrial cancers. Oncotarget 8:4008-4042. DOI: 10.18632/oncotarget.14021.

Bullard JH, Purdom E, Hansen KD, Dudoit S. 2010. Evaluation of statistical methods for normalization and differential expression in mRNA-Seq experiments. BMC Bioinformatics 11. DOI: $10.1186 / 1471-2105-11-94$.

Ciriello G, Miller ML, Aksoy BA, Senbabaoglu Y, Schultz N, Sander C. 2013. Emerging landscape of oncogenic signatures across human cancers. Nature genetics 45:1127-33. DOI: $10.1038 /$ ng. 2762 .

Colaprico A, Silva TC, Olsen C, Garofano L, Cava C, Garolini D, Sabedot TS, Malta TM, Pagnotta SM, Castiglioni I, Ceccarelli M, Bontempi G, Noushmehr H. 2016. TCGAbiolinks: an R/Bioconductor package for integrative analysis of TCGA data. Nucleic acids research 44:e71. DOI: 10.1093/nar/gkv1507.

Cortez AJ, Tudrej P, Kujawa KA, Lisowska KM. 2018. Advances in ovarian cancer therapy. 
445

446

447

448

449

450

451

452

453

454

455

456

457

458

459

460

461

462

463

464

465

466

467

468

469

470

471

472

473

474

475

476

477

478

479

480

481

482

483

484

485

486

487

488

489

490

Cancer Chemotherapy and Pharmacology. DOI: 10.1007/s00280-017-3501-8.

Ge Z, Leighton JS, Wang Y, Peng X, Chen Z, Chen H, Sun Y, Yao F, Li J, Zhang H, Liu J, Shriver CD, Hu H, Cancer Genome Atlas Research Network, Piwnica-Worms H, Ma L, Liang H. 2018. Integrated Genomic Analysis of the Ubiquitin Pathway across Cancer

Types. Cell reports 23:213-226.e3. DOI: 10.1016/j.celrep.2018.03.047.

Getz G, Gabriel SB, Cibulskis K, Lander E, Sivachenko A, Sougnez C, Lawrence M, Kandoth C,

Dooling D, Fulton R, Fulton L, Kalicki-Veizer J, McLellan MD, O’Laughlin M, Schmidt H, Wilson RK, Ye K, Li D, Ally A, Balasundaram M, Birol I, Butterfield YSN, Carlsen R, Carter C, Chu A, Chuah E, Chun HJE, Dhalla N, Guin R, Hirst C, Holt RA, Jones SJM, Lee D, Li HI, Marra MA, Mayo M, Moore RA, Mungall AJ, Plettner P, Schein JE, Sipahimalani P, Tam A, Varhol RJ, Gordon Robertson A, Cherniack AD, Pashtan I, Saksena G, Onofrio RC, Schumacher SE, Tabak B, Carter SL, Hernandez B, Gentry J, Salvesen HB, Ardlie K, Winckler W, Beroukhim R, Meyerson M, Hadjipanayis A, Lee S, Mahadeshwar HS, Park P, Protopopov A, Ren X, Seth S, Song X, Tang J, Xi R, Yang L, Dong Z, Kucherlapati R, Chin L, Zhang J, Todd Auman J, Balu S, Bodenheimer T, Buda E, Neil Hayes D, Hoyle AP, Jefferys SR, Jones CD, Meng S, Mieczkowski PA, Mose LE, Parker JS, Perou CM, Roach J, Yan S, Simons J V., Soloway MG, Tan D, Topal MD, Waring S, Wu J, Hoadley KA, Baylin SB, Bootwalla MS, Lai PH, Triche TJ, Van Den Berg DJ, Weisenberger DJ, Laird PW, Shen H, Cho J, Dicara D, Frazer S, Heiman D, Jing R, Lin P, Mallard W, Stojanov P, Voet D, Zhang H, Zou L, Noble M, Reynolds SM, Shmulevich I, Arman Aksoy B, Antipin Y, Ciriello G, Dresdner G, Gao J, Gross B, Jacobsen A, Ladanyi M, Reva B, Sander C, Sinha R, Onur Sumer S, Taylor BS, Cerami E, Weinhold N, Schultz N, Shen R, Benz S, Goldstein T, Haussler D, Ng S, Szeto C, Stuart J, Benz CC, Yau C, Zhang W, Annala M, Broom BM, Casasent TD, Ju Z, Liang H, Liu G, Lu Y, Unruh AK, Wakefield C, Weinstein JN, Zhang N, Liu Y, Broaddus R, Akbani R, Mills GB, Adams C, Barr T, Black AD, Bowen J, Deardurff J, Frick J, Gastier-Foster JM, Grossman T, Harper HA, HartKothari M, Helsel C, Hobensack A, Kuck H, Kneile K, Leraas KM, Lichtenberg TM, McAllister C, Pyatt RE, Ramirez NC, Tabler TR, Vanhoose N, White P, Wise L, Zmuda E, Barnabas N, Berry-Green C, Blanc V, Boice L, Button M, Farkas A, Green A, MacKenzie J, Nicholson D, Kalloger SE, Blake Gilks C, Karlan BY, Lester J, Orsulic S, Borowsky M, Cadungog M, Czerwinski C, Huelsenbeck-Dill L, Iacocca M, Petrelli N, Rabeno B, Witkin G, Nemirovich-Danchenko E, Potapova O, Rotin D, Berchuck A, Birrer M, Disaia P, Monovich L, Curley E, Gardner J, Mallery D, Penny R, Dowdy SC, Winterhoff B, Dao L, Gostout B, Meuter A, Teoman A, Dao F, Olvera N, Bogomolniy F, Garg K, Soslow RA, Abramov M, Bartlett JMS, Kodeeswaran S, Parfitt J, Moiseenko F, Clarke BA, Goodman MT, Carney ME, Matsuno RK, Fisher J, Huang M, Kimryn Rathmell W, Thorne L, Van Le L, Dhir R, Edwards R, Elishaev E, Zorn K, Goodfellow PJ, Mutch D, Kahn AB, Bell DW, Pollock PM, Wang C, Wheeler D, Shinbrot E, Gordon Robertson A, Ding L, Blake Gilks C, Mardis ER, Ayala B, Chu AL, Jensen MA, Kothiyal P, Pihl TD, Pontius J, Pot DA, Snyder EE, Srinivasan D, Mills Shaw KR, Sheth M, Davidsen T, Eley G, Ferguson ML, Yang L, Guyer MS, Ozenberger BA, Sofia HJ, Gordon Robertson A, Levine DA. 2013. Integrated genomic characterization of endometrial carcinoma. Nature. DOI: 10.1038/nature 12113. Goh WW Bin, Wang W, Wong L. 2017. Why Batch Effects Matter in Omics Data, and How to Avoid Them. Trends in Biotechnology 35:498-507. DOI: 10.1016/j.tibtech.2017.02.012. Goode EL, Block MS, Kalli KR, Vierkant RA, Chen W, Fogarty ZC, Gentry-Maharaj A, Tołoczko A, Hein A, Bouligny AL, Jensen A, Osorio A, Hartkopf A, Ryan A, Chudecka- 
491

492

493

494

495

496

497

498

499

500

501

502

503

504

505

506

507

508

509

510

511

512

513

514

515

516

517

518

519

520

521

522

523

524

525

526

527

528

529

530

531

532

533

534

535

536

Głaz A, Magliocco AM, Hartmann A, Jung AY, Gao B, Hernandez BY, Fridley BL, McCauley BM, Kennedy CJ, Wang C, Karpinskyj C, de Sousa CB, Tiezzi DG, Wachter DL, Herpel E, Taran FA, Modugno F, Nelson G, Lubiński J, Menkiszak J, Alsop J, Lester J, García-Donas J, Nation J, Hung J, Palacios J, Rothstein JH, Kelley JL, de Andrade JM, Robles-Díaz L, Intermaggio MP, Widschwendter M, Beckmann MW, Ruebner M, JimenezLinan M, Singh N, Oszurek O, Harnett PR, Rambau PF, Sinn P, Wagner P, Ghatage P, Sharma R, Edwards RP, Ness RB, Orsulic S, Brucker SY, Johnatty SE, Longacre TA, Ursula E, McGuire V, Sieh W, Natanzon Y, Li Z, Whittemore AS, Anna de F, Staebler A, Karlan BY, Gilks B, Bowtell DD, Høgdall E, Candido dos Reis FJ, Steed H, Campbell IG, Gronwald J, Benítez J, Koziak JM, Chang-Claude J, Moysich KB, Kelemen LE, Cook LS, Goodman MT, García MJ, Fasching PA, Kommoss S, Deen S, Kjaer SK, Menon U, Brenton JD, Pharoah PDP, Chenevix-Trench G, Huntsman DG, Winham SJ, Köbel M, Ramus SJ. 2017. Dose-Response Association of CD8+ Tumor-Infiltrating Lymphocytes and Survival Time in High-Grade Serous Ovarian Cancer. JAMA oncology 3:e173290. DOI: 10.1001/jamaoncol.2017.3290.

Hanzelmann S, Castelo R, Guinney J. 2013. GSVA: gene set variation analysis for microarray and RNA-seq data. BMC Bioinformatics 14:7. DOI: 10.1186/1471-2105-14-7.

Havel JJ, Chowell D, Chan TA. 2019. The evolving landscape of biomarkers for checkpoint inhibitor immunotherapy. Nature Reviews Cancer 19:133-150. DOI: 10.1038/s41568-0190116-x.

Heim D, Budczies J, Stenzinger A, Treue D, Hufnagl P, Denkert C, Dietel M, Klauschen F. Cancer beyond organ and tissue specificity: Next-generation-sequencing gene mutation data reveal complex genetic similarities across major cancers. DOI: 10.1002/ijc.28882.

Hemminki A, Markie D, Tomlinson I, Avizienyte E, Roth S, Loukola A, Bignell G, Warren W, Aminoff M, Hoglund P, Jarvinen H, Kristo P, Pelin K, Ridanpaa M, Salovaara R, Toro T, Bodmer W, Olschwang S, Olsen AS, Stratton MR, de la Chapelle A, Aaltonen LA. 1998. A serine/threonine kinase gene defective in Peutz-Jeghers syndrome. Nature 391:184-187. DOI: $10.1038 / 34432$.

Hoadley KA, Yau C, Hinoue T, Wolf DM, Lazar AJ, Drill E, Shen R, Taylor AM, Cherniack AD, Thorsson V, Akbani R, Bowlby R, Wong CK, Wiznerowicz M, Sanchez-Vega F, Robertson AG, Schneider BG, Lawrence MS, Noushmehr H, Malta TM, Cancer Genome Atlas Network, Stuart JM, Benz CC, Laird PW. 2018a. Cell-of-Origin Patterns Dominate the Molecular Classification of 10,000 Tumors from 33 Types of Cancer. Cell 173:291304.e6. DOI: 10.1016/j.cell.2018.03.022.

Hoadley KA, Yau C, Stuart JM, Benz CC, Correspondence PWL. 2018b. Cell-of-Origin Patterns Dominate the Molecular Classification of 10,000 Tumors from 33 Types of Cancer. Cell 173:291-304.e6. DOI: 10.1016/j.cell.2018.03.022.

Hopkins Hospital Edward Tanner J, Santin A, Tran A-Q, Gehrig P. 2017. Open Peer Review Recent Advances in Endometrial Cancer [version 1; referees: 2 approved]. F1000 Faculty Rev. DOI: 10.12688/f1000research.10020.1.

Leek JT, Johnson EW, Parker HS, Fertig EJ, Jaffe AE, Storey JD, Zhang Y, Torres LC. 2018. Bioconductor - sva: Surrogate Variable Analysis. DOI: 10.18129/B9.bioc.sva.

Li B, Liu JS, Liu XS. 2017. Revisit linear regression-based deconvolution methods for tumor gene expression data. Genome Biology 18. DOI: 10.1186/s13059-017-1256-5.

Li B, Severson E, Pignon JC, Zhao H, Li T, Novak J, Jiang P, Shen H, Aster JC, Rodig S, Signoretti S, Liu JS, Liu XS. 2016. Comprehensive analyses of tumor immunity:

Peer) reviewing PDF | (2019:07:39898:2:0:NEW 26 Nov 2019) 
537

538

539

540

541

542

543

544

545

546

547

548

549

550

551

552

553

554

555

556

557

558

559

560

561

562

563

564

565

566

567

568

569

570

571

572

573

574

575

576

577

578

579

580

581

582
Implications for cancer immunotherapy. Genome Biology 17. DOI: 10.1186/s13059-0161028-7.

Liao Y, Wang J, Jaehnig EJ, Shi Z, Zhang B. 2019. WebGestalt 2019: gene set analysis toolkit with revamped UIs and APIs. Nucleic Acids Research. DOI: 10.1093/nar/gkz401.

Liberzon A, Birger C, Thorvaldsdottir H, Ghandi M, Mesirov JP, Tamayo P. 2015. The Molecular Signatures Database (MSigDB) hallmark gene set collection. Cell Syst 1:417425. DOI: 10.1016/j.cels.2015.12.004.

Liu X, Yu X, Zack DJ, Zhu H, Qian J. 2008. TiGER: A database for tissue-specific gene expression and regulation. BMC Bioinformatics. DOI: 10.1186/1471-2105-9-271.

Makker V, Green AK, Wenham RM, Mutch D, Davidson B, Miller DS. 2017. New therapies for advanced, recurrent, and metastatic endometrial cancers. Gynecologic Oncology Research and Practice 4. DOI: 10.1186/s40661-017-0056-7.

Margolin AA, Mills GB, Stuart JM, Weinstein JN, Yau C, Niu B, Akbani R, Wolf DM, Benz CC, Tamborero D, Perou CM, Shen H, Collisson EA, Kandoth C, Ng S, Zhang J, Byers LA, Cherniack AD, Leiserson MDM, Laird PW, Raphael BJ, Hoadley KA, Lopez-Bigas N, McLellan MD, Van Waes C, Chen Z, Omberg L, Robertson AG, van't Veer LJ, Chu A, Ding L, Uzunangelov V. 2014. Multiplatform Analysis of 12 Cancer Types Reveals Molecular Classification within and across Tissues of Origin. Cell. DOI: 10.1016/j.cell.2014.06.049.

Matulonis UA, Sood AK, Fallowfield L, Howitt BE, Sehouli J, Karlan BY. 2016. Ovarian cancer. Nature Reviews Disease Primers 2:16061. DOI: 10.1038/nrdp.2016.61.

Mayakonda A, Lin DC, Assenov Y, Plass C, Koeffler HP. 2018. Maftools: Efficient and comprehensive analysis of somatic variants in cancer. Genome Research 28:1747-1756. DOI: $10.1101 /$ gr.239244.118.

Mougiakakos D, Choudhury A, Lladser A, Kiessling R, Johansson CC. 2010. Regulatory T cells in cancer. Advances in cancer research 107:57-117. DOI: 10.1016/S0065-230X(10)07003$\mathrm{X}$.

Moxley KM, McMeekin DS. 2010. Endometrial Carcinoma: A Review of Chemotherapy, Drug Resistance, and the Search for New Agents. The Oncologist. DOI: 10.1634/theoncologist.2010-0087.

Mullen RD, Behringer RR. 2014. Molecular genetics of Müllerian duct formation, regression and differentiation. Sexual development : genetics, molecular biology, evolution, endocrinology, embryology, and pathology of sex determination and differentiation 8:281-96. DOI: $10.1159 / 000364935$.

Murphy PM. 2012. Chemokines and chemokine receptors. In: Clinical Immunology: Principles and Practice: Fourth Edition. Elsevier Inc., 136-148. DOI: 10.1016/B978-0-7234-36911.00034-9.

Newman AM, Gentles AJ, Liu CL, Diehn M, Alizadeh AA. 2017. Data normalization considerations for digital tumor dissection. Genome Biology 18. DOI: 10.1186/s13059-0171257-4.

Newman AM, Liu CL, Green MR, Gentles AJ, Feng W, Xu Y, Hoang CD, Diehn M, Alizadeh AA. 2015. Robust enumeration of cell subsets from tissue expression profiles. Nature methods 12:453-7. DOI: 10.1038/nmeth.3337.

Nygaard V, Rødland EA, Hovig E. 2016. Methods that remove batch effects while retaining group differences may lead to exaggerated confidence in downstream analyses. Biostatistics 17:29-39. DOI: 10.1093/biostatistics/kxv027.

Peer) reviewing PDF | (2019:07:39898:2:0:NEW 26 Nov 2019) 
583 Oh D-Y, Bang Y-J. 2019. HER2-targeted therapies - a role beyond breast cancer. Nature

584

585

586

587

588

589

590

591

592

593

594

595

596

597

598

599

600

601

602

603

604

605

606

607

608

609

610

611

612

613

614

615

616

617

618

619

620

621

622

623

624

625

626

627

628 reviews. Clinical oncology. DOI: 10.1038/s41571-019-0268-3.

Oytam Y, Sobhanmanesh F, Duesing K, Bowden JC, Osmond-McLeod M, Ross J. 2016. Riskconscious correction of batch effects: maximising information extraction from highthroughput genomic datasets. BMC Bioinformatics 17:332. DOI: 10.1186/s12859-0161212-5.

Pallen MJ. 2003. Glucoamylase-like domains in the alpha- and beta-subunits of phosphorylase kinase. Protein science : a publication of the Protein Society 12:1804-7. DOI: 10.1110/ps.0371103.

Piulats JM, Matias-Guiu X. 2016. Immunotherapy in endometrial cancer: In the nick of time. Clinical Cancer Research. DOI: 10.1158/1078-0432.CCR-16-1820.

Rooney MS, Shukla SA, Wu CJ, Getz G, Hacohen N. 2015. Molecular and genetic properties of tumors associated with local immune cytolytic activity. Cell 160:48-61. DOI: 10.1016/j.cell.2014.12.033.

Rosario SR, Long MD, Affronti HC, Rowsam AM, Eng KH, Smiraglia DJ. 2018. Pan-cancer analysis of transcriptional metabolic dysregulation using The Cancer Genome Atlas. Nature Communications 9. DOI: 10.1038/s41467-018-07232-8.

Schubert M, Klinger B, Klünemann M, Sieber A, Uhlitz F, Sauer S, Garnett MJ, Blüthgen N, Saez-Rodriguez J. 2018. Perturbation-response genes reveal signaling footprints in cancer gene expression. Nature Communications 9. DOI: 10.1038/s41467-017-02391-6.

Shivapurkar N, Virmani AK, Wistuba II, Milchgrub S, Mackay B, Minna JD, Gazdar AF. 1999. Deletions of chromosome 4 at multiple sites are frequent in malignant mesothelioma and small cell lung carcinoma. Clinical cancer research : an official journal of the American Association for Cancer Research 5:17-23.

Siegel RL, Miller KD, Jemal A. 2019. Cancer statistics, 2019. CA: A Cancer Journal for Clinicians 69:7-34. DOI: 10.3322/caac.21551.

Singh RK, Indra D, Mitra S, Mondal RK, Basu PS, Roy A, Roychowdhury S, Panda CK. 2007. Deletions in chromosome 4 differentially associated with the development of cervical cancer: Evidence of slit 2 as a candidate tumor suppressor gene. Human Genetics 122:7181. DOI: $10.1007 / \mathrm{s} 00439-007-0375-6$.

Subramanian A, Tamayo P, Mootha VK, Mukherjee S, Ebert BL, Gillette MA, Paulovich A, Pomeroy SL, Golub TR, Lander ES, Mesirov JP. 2005. Gene set enrichment analysis: a knowledge-based approach for interpreting genome-wide expression profiles. Proc Natl Acad Sci U S A 102:15545-15550. DOI: 10.1073/pnas.0506580102.

Terry M, Therneau M. 2019. Package "survival” Title Survival Analysis.

Thorsson V, Gibbs DL, Brown SD, Wolf D, Bortone DS, Ou Yang TH, Porta-Pardo E, Gao GF, Plaisier CL, Eddy JA, Ziv E, Culhane AC, Paull EO, Sivakumar IKA, Gentles AJ, Malhotra R, Farshidfar F, Colaprico A, Parker JS, Mose LE, Vo NS, Liu J, Liu Y, Rader J, Dhankani V, Reynolds SM, Bowlby R, Califano A, Cherniack AD, Anastassiou D, Bedognetti D, Rao A, Chen K, Krasnitz A, Hu H, Malta TM, Noushmehr H, Pedamallu CS, Bullman S, Ojesina AI, Lamb A, Zhou W, Shen H, Choueiri TK, Weinstein JN, Guinney J, Saltz J, Holt RA, Rabkin CE, Caesar-Johnson SJ, Demchok JA, Felau I, Kasapi M, Ferguson ML, Hutter CM, Sofia HJ, Tarnuzzer R, Wang Z, Yang L, Zenklusen JC, Zhang J (Julia), Chudamani S, Liu J, Lolla L, Naresh R, Pihl T, Sun Q, Wan Y, Wu Y, Cho J, DeFreitas T, Frazer S, Gehlenborg N, Getz G, Heiman DI, Kim J, Lawrence MS, Lin P, Meier S, Noble MS, Saksena G, Voet D, Zhang H, Bernard B, Chambwe N, Dhankani V, Knijnenburg T, 
629

630

631

632

633

634

635

636

637

638

639

640

641

642

643

644

645

646

647

648

649

650

651

652

653

654

655

656

657

658

659

660

661

662

663

664

665

666

667

668

669

670

671

672

673

674
Kramer R, Leinonen K, Liu Y, Miller M, Reynolds S, Shmulevich I, Thorsson V, Zhang W, Akbani R, Broom BM, Hegde AM, Ju Z, Kanchi RS, Korkut A, Li J, Liang H, Ling S, Liu W, Lu Y, Mills GB, Ng KS, Rao A, Ryan M, Wang J, Weinstein JN, Zhang J, Abeshouse A, Armenia J, Chakravarty D, Chatila WK, de Bruijn I, Gao J, Gross BE, Heins ZJ, Kundra R, La K, Ladanyi M, Luna A, Nissan MG, Ochoa A, Phillips SM, Reznik E, Sanchez-Vega F, Sander C, Schultz N, Sheridan R, Sumer SO, Sun Y, Taylor BS, Wang J, Zhang H, Anur P, Peto M, Spellman P, Benz C, Stuart JM, Wong CK, Yau C, Hayes DN, Parker JS, Wilkerson MD, Ally A, Balasundaram M, Bowlby R, Brooks D, Carlsen R, Chuah E, Dhalla N, Holt R, Jones SJM, Kasaian K, Lee D, Ma Y, Marra MA, Mayo M, Moore RA, Mungall AJ, Mungall K, Robertson AG, Sadeghi S, Schein JE, Sipahimalani P, Tam A, Thiessen N, Tse K, Wong T, Berger AC, Beroukhim R, Cherniack AD, Cibulskis C, Gabriel SB, Gao GF, Ha G, Meyerson M, Schumacher SE, Shih J, Kucherlapati MH, Kucherlapati RS, Baylin S, Cope L, Danilova L, Bootwalla MS, Lai PH, Maglinte DT, Van Den Berg DJ, Weisenberger DJ, Auman JT, Balu S, Bodenheimer T, Fan C, Hoadley KA, Hoyle AP, Jefferys SR, Jones CD, Meng S, Mieczkowski PA, Mose LE, Perou AH, Perou CM, Roach J, Shi Y, Simons J V., Skelly T, Soloway MG, Tan D, Veluvolu U, Fan H, Hinoue T, Laird PW, Shen H, Zhou W, Bellair M, Chang K, Covington K, Creighton CJ, Dinh H, Doddapaneni HV, Donehower LA, Drummond J, Gibbs RA, Glenn R, Hale W, Han Y, Hu J, Korchina V, Lee S, Lewis L, Li W, Liu X, Morgan M, Morton D, Muzny D, Santibanez J, Sheth M, Shinbrot E, Wang L, Wang M, Wheeler DA, Xi L, Zhao F, Hess J, Appelbaum EL, Bailey M, Cordes MG, Ding L, Fronick CC, Fulton LA, Fulton RS, Kandoth C, Mardis ER, McLellan MD, Miller CA, Schmidt HK, Wilson RK, Crain D, Curley E, Gardner J, Lau K, Mallery D, Morris S, Paulauskis J, Penny R, Shelton C, Shelton T, Sherman M, Thompson E, Yena P, Bowen J, Gastier-Foster JM, Gerken M, Leraas KM, Lichtenberg TM, Ramirez NC, Wise L, Zmuda E, Corcoran N, Costello T, Hovens C, Carvalho AL, de Carvalho AC, Fregnani JH, Longatto-Filho A, Reis RM, Scapulatempo-Neto C, Silveira HCS, Vidal DO, Burnette A, Eschbacher J, Hermes B, Noss A, Singh R, Anderson ML, Castro PD, Ittmann M, Huntsman D, Kohl B, Le X, Thorp R, Andry C, Duffy ER, Lyadov V, Paklina O, Setdikova G, Shabunin A, Tavobilov M, McPherson C, Warnick R, Berkowitz R, Cramer D, Feltmate C, Horowitz N, Kibel A, Muto M, Raut CP, Malykh A, Barnholtz-Sloan JS, Barrett W, Devine K, Fulop J, Ostrom QT, Shimmel K, Wolinsky Y, Sloan AE, De Rose A, Giuliante F, Goodman M, Karlan BY, Hagedorn CH, Eckman J, Harr J, Myers J, Tucker K, Zach LA, Deyarmin B, Hu H, Kvecher L, Larson C, Mural RJ, Somiari S, Vicha A, Zelinka T, Bennett J, Iacocca M, Rabeno B, Swanson P, Latour M, Lacombe L, Têtu B, Bergeron A, McGraw M, Staugaitis SM, Chabot J, Hibshoosh H, Sepulveda A, Su T, Wang T, Potapova O, Voronina O, Desjardins L, Mariani O, Roman-Roman S, Sastre X, Stern MH, Cheng F, Signoretti S, Berchuck A, Bigner D, Lipp E, Marks J, McCall S, McLendon R, Secord A, Sharp A, Behera M, Brat DJ, Chen A, Delman K, Force S, Khuri F, Magliocca K, Maithel S, Olson JJ, Owonikoko T, Pickens A, Ramalingam S, Shin DM, Sica G, Van Meir EG, Zhang H, Eijckenboom W, Gillis A, Korpershoek E, Looijenga L, Oosterhuis W, Stoop H, van Kessel KE, Zwarthoff EC, Calatozzolo C, Cuppini L, Cuzzubbo S, DiMeco F, Finocchiaro G, Mattei L, Perin A, Pollo B, Chen C, Houck J, Lohavanichbutr P, Hartmann A, Stoehr C, Stoehr R, Taubert H, Wach S, Wullich B, Kycler W, Murawa D, Wiznerowicz M, Chung K, Edenfield WJ, Martin J, Baudin E, Bubley G, Bueno R, De Rienzo A, Richards WG, Kalkanis S, Mikkelsen T, Noushmehr H, Scarpace L, Girard N, Aymerich M, Campo E, 
675

676

677

678

679

680

681

682

683

684

685

686

687

688

689

690

691

692

693

694

695

696

697

698

699

700

701

702

703

704

705

706

707

708

709

710

711

712

713

714

715

716

717

718

719

720

Giné E, Guillermo AL, Van Bang N, Hanh PT, Phu BD, Tang Y, Colman H, Evason K, Dottino PR, Martignetti JA, Gabra H, Juhl H, Akeredolu T, Stepa S, Hoon D, Ahn K, Kang KJ, Beuschlein F, Breggia A, Birrer M, Bell D, Borad M, Bryce AH, Castle E, Chandan V, Cheville J, Copland JA, Farnell M, Flotte T, Giama N, Ho T, Kendrick M, Kocher JP, Kopp K, Moser C, Nagorney D, O’Brien D, O’Neill BP, Patel T, Petersen G, Que F, Rivera M, Roberts L, Smallridge R, Smyrk T, Stanton M, Thompson RH, Torbenson M, Yang JD, Zhang L, Brimo F, Ajani JA, Gonzalez AMA, Behrens C, Bondaruk J, Broaddus R, Czerniak B, Esmaeli B, Fujimoto J, Gershenwald J, Guo C, Lazar AJ, Logothetis C, MericBernstam F, Moran C, Ramondetta L, Rice D, Sood A, Tamboli P, Thompson T, Troncoso P, Tsao A, Wistuba I, Carter C, Haydu L, Hersey P, Jakrot V, Kakavand H, Kefford R, Lee K, Long G, Mann G, Quinn M, Saw R, Scolyer R, Shannon K, Spillane A, Stretch onathan, Synott M, Thompson J, Wilmott J, Al-Ahmadie H, Chan TA, Ghossein R, Gopalan A, Levine DA, Reuter V, Singer S, Singh B, Tien NV, Broudy T, Mirsaidi C, Nair P, Drwiega P, Miller J, Smith J, Zaren H, Park JW, Hung NP, Kebebew E, Linehan WM, Metwalli AR, Pacak K, Pinto PA, Schiffman M, Schmidt LS, Vocke CD, Wentzensen N, Worrell R, Yang H, Moncrieff M, Goparaju C, Melamed J, Pass H, Botnariuc N, Caraman I, Cernat M, Chemencedji I, Clipca A, Doruc S, Gorincioi G, Mura S, Pirtac M, Stancul I, Tcaciuc D, Albert M, Alexopoulou I, Arnaout A, Bartlett J, Engel J, Gilbert S, Parfitt J, Sekhon H, Thomas G, Rassl DM, Rintoul RC, Bifulco C, Tamakawa R, Urba W, Hayward N, Timmers H, Antenucci A, Facciolo F, Grazi G, Marino M, Merola R, de Krijger R, GimenezRoqueplo AP, Piché A, Chevalier S, McKercher G, Birsoy K, Barnett G, Brewer C, Farver C, Naska T, Pennell NA, Raymond D, Schilero C, Smolenski K, Williams F, Morrison C, Borgia JA, Liptay MJ, Pool M, Seder CW, Junker K, Omberg L, Dinkin M, Manikhas G, Alvaro D, Bragazzi MC, Cardinale V, Carpino G, Gaudio E, Chesla D, Cottingham S, Dubina M, Moiseenko F, Dhanasekaran R, Becker KF, Janssen KP, Slotta-Huspenina J, Abdel-Rahman MH, Aziz D, Bell S, Cebulla CM, Davis A, Duell R, Elder JB, Hilty J, Kumar B, Lang J, Lehman NL, Mandt R, Nguyen P, Pilarski R, Rai K, Schoenfield L, Senecal K, Wakely P, Hansen P, Lechan R, Powers J, Tischler A, Grizzle WE, Sexton KC, Kastl A, Henderson J, Porten S, Waldmann J, Fassnacht M, Asa SL, Schadendorf D, Couce M, Graefen M, Huland H, Sauter G, Schlomm T, Simon R, Tennstedt P, Olabode O, Nelson M, Bathe O, Carroll PR, Chan JM, Disaia P, Glenn P, Kelley RK, Landen CN, Phillips J, Prados M, Simko J, Smith-McCune K, VandenBerg S, Roggin K, Fehrenbach A, Kendler A, Sifri S, Steele R, Jimeno A, Carey F, Forgie I, Mannelli M, Carney M, Hernandez B, Campos B, Herold-Mende C, Jungk C, Unterberg A, von Deimling A, Bossler A, Galbraith J, Jacobus L, Knudson M, Knutson T, Ma D, Milhem M, Sigmund R, Godwin AK, Madan R, Rosenthal HG, Adebamowo C, Adebamowo SN, Boussioutas A, Beer D, Giordano T, Mes-Masson AM, Saad F, Bocklage T, Landrum L, Mannel R, Moore K, Moxley K, Postier R, Walker J, Zuna R, Feldman M, Valdivieso F, Dhir R, Luketich J, Pinero EMM, Quintero-Aguilo M, Carlotti CG, Dos Santos JS, Kemp R, Sankarankuty A, Tirapelli D, Catto J, Agnew K, Swisher E, Creaney J, Robinson B, Shelley CS, Godwin EM, Kendall S, Shipman C, Bradford C, Carey T, Haddad A, Moyer J, Peterson L, Prince M, Rozek L, Wolf G, Bowman R, Fong KM, Yang I, Korst R, Rathmell WK, Fantacone-Campbell JL, Hooke JA, Kovatich AJ, Shriver CD, DiPersio J, Drake B, Govindan R, Heath S, Ley T, Van Tine B, Westervelt P, Rubin MA, Lee J Il, Aredes ND, Mariamidze A, Serody JS, Demicco EG, Disis ML, Vincent BG, Shmulevich 1lya. 2018. The Immune Landscape of Cancer. Immunity. DOI: 10.1016/j.immuni.2018.03.023.

Peer] reviewing PDF | (2019:07:39898:2:0:NEW 26 Nov 2019) 
721

722

723

724

725

726

727

728

729

730

731

732

733

734

735

736

737

738

739

740

741

742

743

744

745

746

747

748

749

750

751

752

753
Tung NM, Garber JE. 2018. BRCA1/2 testing: Therapeutic implications for breast cancer management. British Journal of Cancer 119:141-152. DOI: 10.1038/s41416-018-0127-5.

Valkenburg KC, De Groot AE, Pienta KJ. 2018. Targeting the tumour stroma to improve cancer therapy. Nature Reviews Clinical Oncology. DOI: 10.1038/s41571-018-0007-1.

Vasaikar S, Huang C, Wang X, Petyuk VA, Savage SR, Wen B, Dou Y, Zhang Y, Shi Z, Arshad OA, Gritsenko MA, Zimmerman LJ, McDermott JE, Clauss TR, Moore RJ, Zhao R, Monroe ME, Wang YT, Chambers MC, Slebos RJC, Lau KS, Mo Q, Ding L, Ellis M, Thiagarajan M, Kinsinger CR, Rodriguez H, Smith RD, Rodland KD, Liebler DC, Liu T, Zhang B, Ellis MJC, Bavarva J, Borucki M, Elburn K, Hannick L, Vatanian N, Payne SH, Carr SA, Clauser KR, Gillette MA, Kuhn E, Mani DR, Cai S, Ketchum KA, Thangudu RR, Whiteley GA, Paulovich A, Whiteaker J, Edward NJ, Madhavan S, McGarvey PB, Chan DW, Shih IM, Zhang H, Zhang Z, Zhu H, Skates SJ, White FM, Mertins P, Pandey A, Slebos RJC, Boja E, Hiltke T, Mesri M, Rivers RC, Stein SE, Fenyo D, Ruggles K, Levine DA, Oberti M, Rudnick PA, Snyder M, Tabb DL, Zhao Y, Chen X, Ransohoff DF, Hoofnagle A, Sanders ME, Wang Y, Davies SR, Townsend RR, Watson M. 2019. Proteogenomic Analysis of Human Colon Cancer Reveals New Therapeutic Opportunities. Cell. DOI: 10.1016/j.cell.2019.03.030.

Wang Z, Jensen MA, Zenklusen JC. 2016. A practical guide to The Cancer Genome Atlas (TCGA). In: Methods in Molecular Biology. DOI: 10.1007/978-1-4939-3578-9_6.

Wang X-L, Uzawa K, Tanzawa H. Localization of a novel tumor suppressor gene associated with human oral cancer on chromosome 4q25.

Wilken JA, Badri T, Cross S, Raji R, Santin AD, Schwartz P, Branscum AJ, Baron AT, Sakhitab AI, Maihle NJ. 2012. EGFR/HER-targeted therapeutics in ovarian cancer. Future Medicinal Chemistry 4:447-469. DOI: 10.4155/fmc.12.11.

Yoshihara K, Shahmoradgoli M, Martínez E, Vegesna R, Kim H, Torres-Garcia W, Treviño V, Shen H, Laird PW, Levine DA, Carter SL, Getz G, Stemke-Hale K, Mills GB, Verhaak RGW. 2013. Inferring tumour purity and stromal and immune cell admixture from expression data. Nature Communications. DOI: 10.1038/ncomms3612.

Zhang Z, Ye Y, Gong J, Ruan H, Liu C-J, Xiang Y, Cai C, Guo A-Y, Ling J, Diao L, Weinstein JN, Han L. 2018. Global analysis of tRNA and translation factor expression reveals a dynamic landscape of translational regulation in human cancers. Communications Biology. DOI: $10.1038 / \mathrm{s} 42003-018-0239-8$. 


\section{Figure 1}

The somatic copy number alternation (SCNA) of the three cancer types

(A) Heatmap showing the SCNA landscape. Each row corresponds to one TCGA sample while each column corresponds to one chromosome. (B) PCA plot displaying the quantifications of all chromosome instabilities (i.e. summarized genome-wide total SCNAs) for these three cancer types. (C) Box plot comparing the arm-level amplification and deletion for all the 22 autosomes. Note that for every arm, the SCNA strength is weaker in endometroid EC compared to serous-like EC or serous OvCa. The star marks $(*)$ denote the arms whose SCNAs are stronger in serous OvCa compared to serous-like EC (adjusted $\mathrm{p}$ value $<0.05$, Student's t-test). (D-E) The comparison of summarized genome-wide SCNA strengths (amplification and deletion, respectively) across the three cancer types. $\mathrm{P}$ values were resulted from Student's t-test. 
A Chromosome:
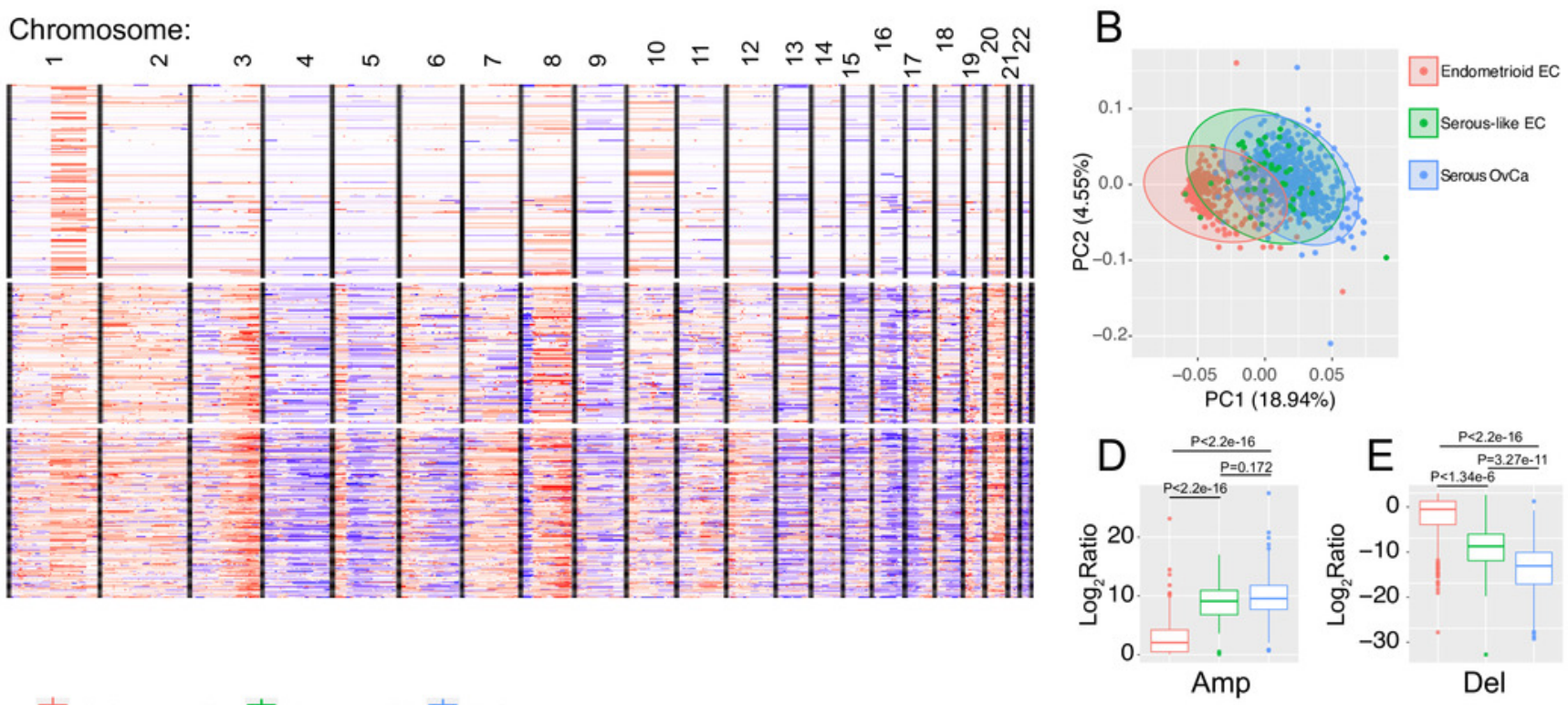

C

官 Endometrioid EC 官 Serous-like EC 户 OrCa

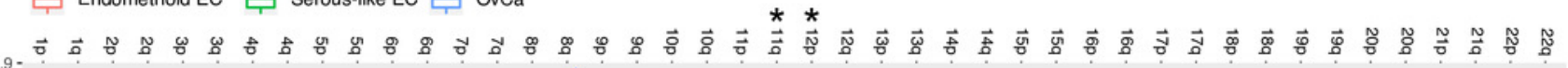

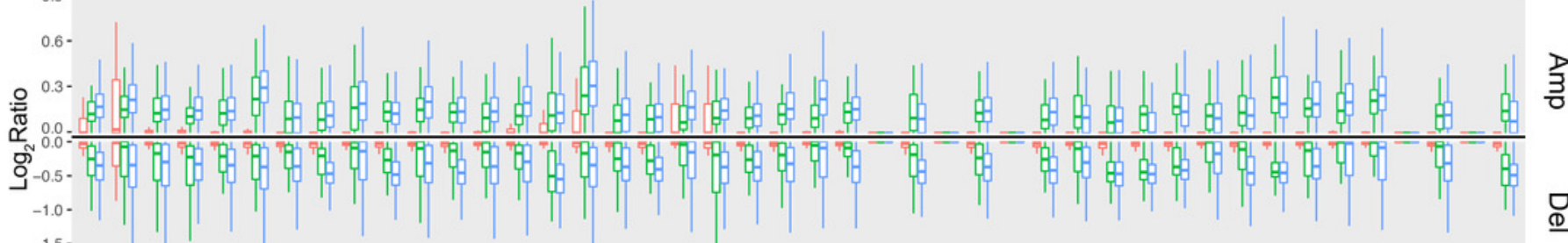

$-1.5-$

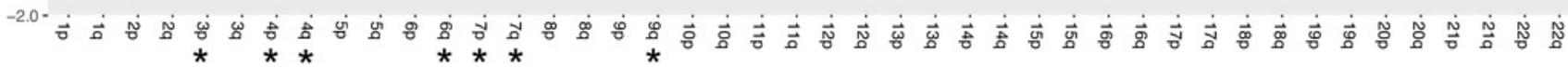




\section{Figure 2}

The comparison of somatic mutation (SM) among the three cancer types.

(A) The overall SM burdens. P values were resulted from student's t-test. (B-D) The top 20 most frequently mutated genes for endometroid EC (B), serous-like EC (C) and serous OvCa (D). The $y$-axis of the bar plots represents the SM proportions of all available TCGA samples from each indicated cancer type. (E-G) Scatter plots show the rates of gene mutation and gene copy number change for the most important cancer driver genes within each of the three cancer types. P values listed below were resulted from Kolmogorov-Smirnovtest comparing the cumulative patterns between gene mutation and gene copy number change.
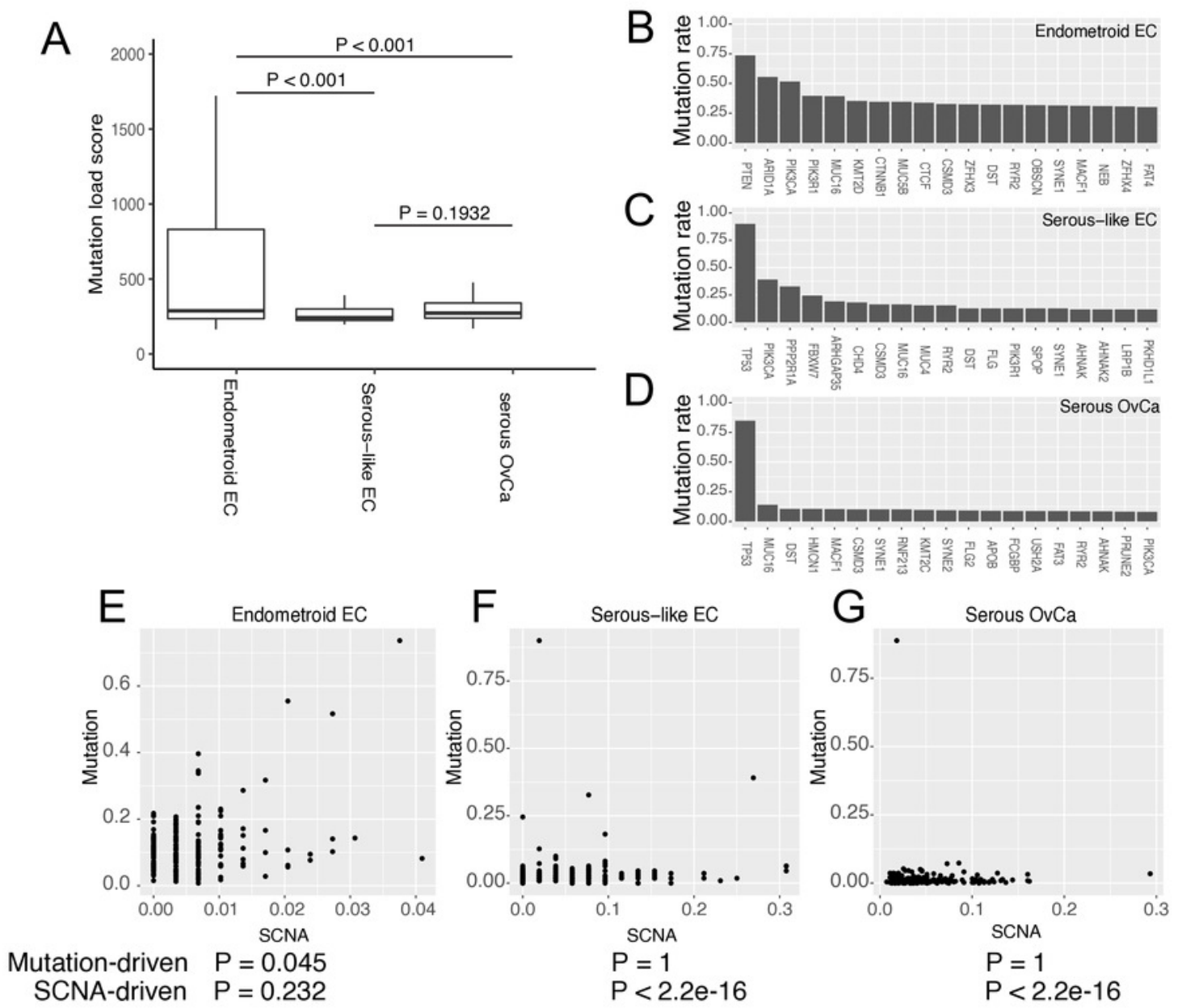


\section{Figure 3}

The comparison of gene expression and pathway activity among the three cancer types.

(A) PCA plot showing the overall gene expression similarity of all available samples from these three cancer types. (B) Boxplot showing the Spearman's correlation coefficients of all possible sample pairs from different cancer type. $P$ values were resulted from Student's ttest. (C-D) Boxplots comparing the organ-specific gene expression, including uterine-specific (C) and ovary-specific (D) from these three cancer types. (E) Relative pathway activities of the hallmark pathways shown by heatmap. For simplicity, only the significantly variable pathways (adjusted P value $<0.01$, One-way ANOVA) were shown. Two specific clusters, immune related pathways (cluster 1 ) and metabolism-related pathways (cluster 2) were highlighted to show the similarities between the two ECs and the two "serous" cancer types, respectively (see main text). 

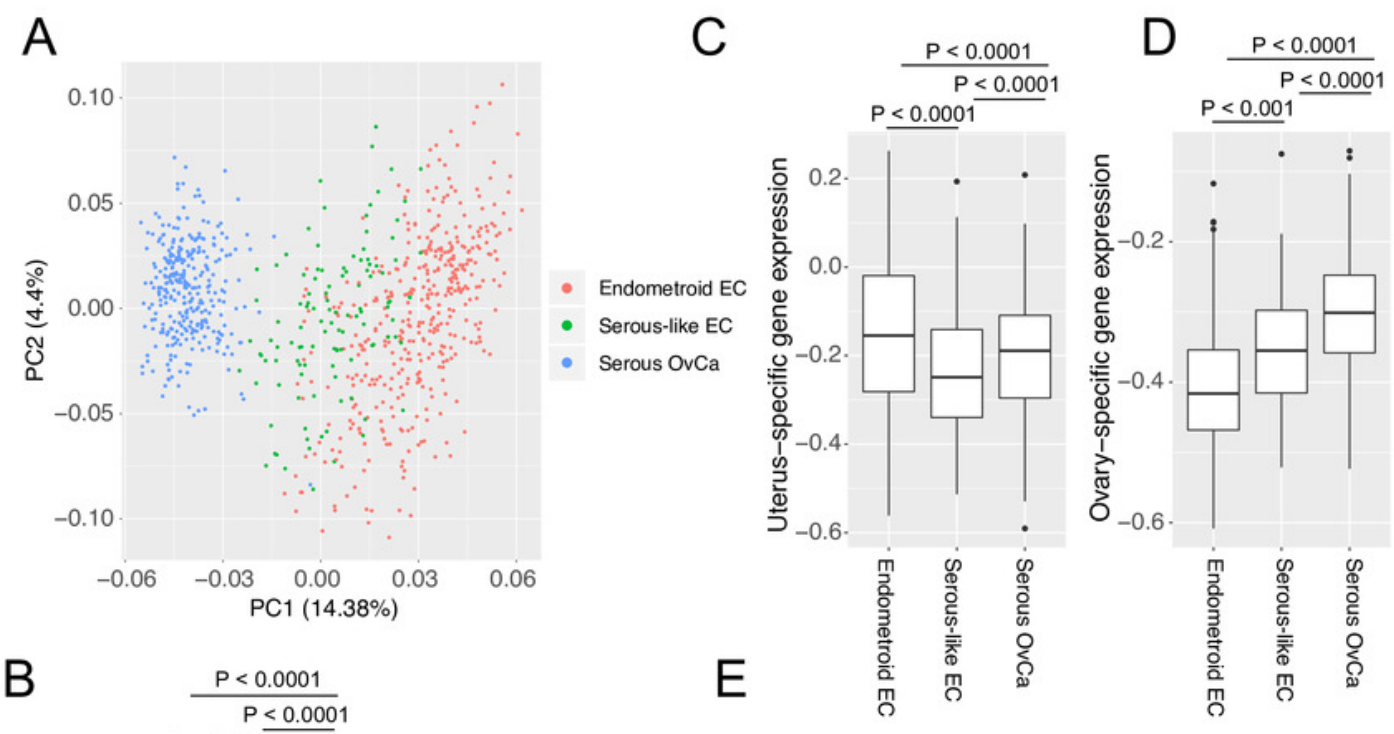

B

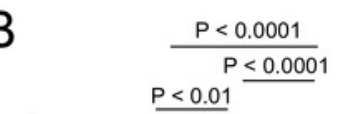

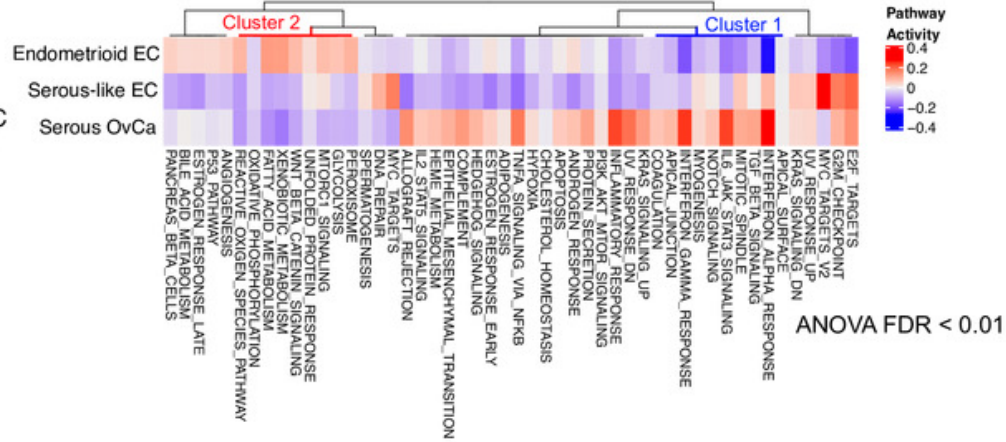




\section{Figure 4}

Survival signature pathways and genes for the three cancer types.

(A) Kaplan-Meier curve comparing the overall survival for the three cancer types. The P value was resulted from log-rank test. (B-D) Signaling pathways related to survival outcome for endometroid EC (B), serous-like EC (C) and serous OvCa (D). The blue pathways indicate adverse prognostic while the yellow pathways indicate favorable prognostic. All the pathways on display have adjusted P-value less than 0.01 (based on GSEA permutation). (E-J) KaplanMeier curve showing two representative genes that have common prognostic values for the two EC types but not serous OvCa. PHKAI (E-G) is an adverse prognostic gene while CXCR5 $(\mathrm{H}-\mathrm{J})$ is a favorable prognostic gene. 

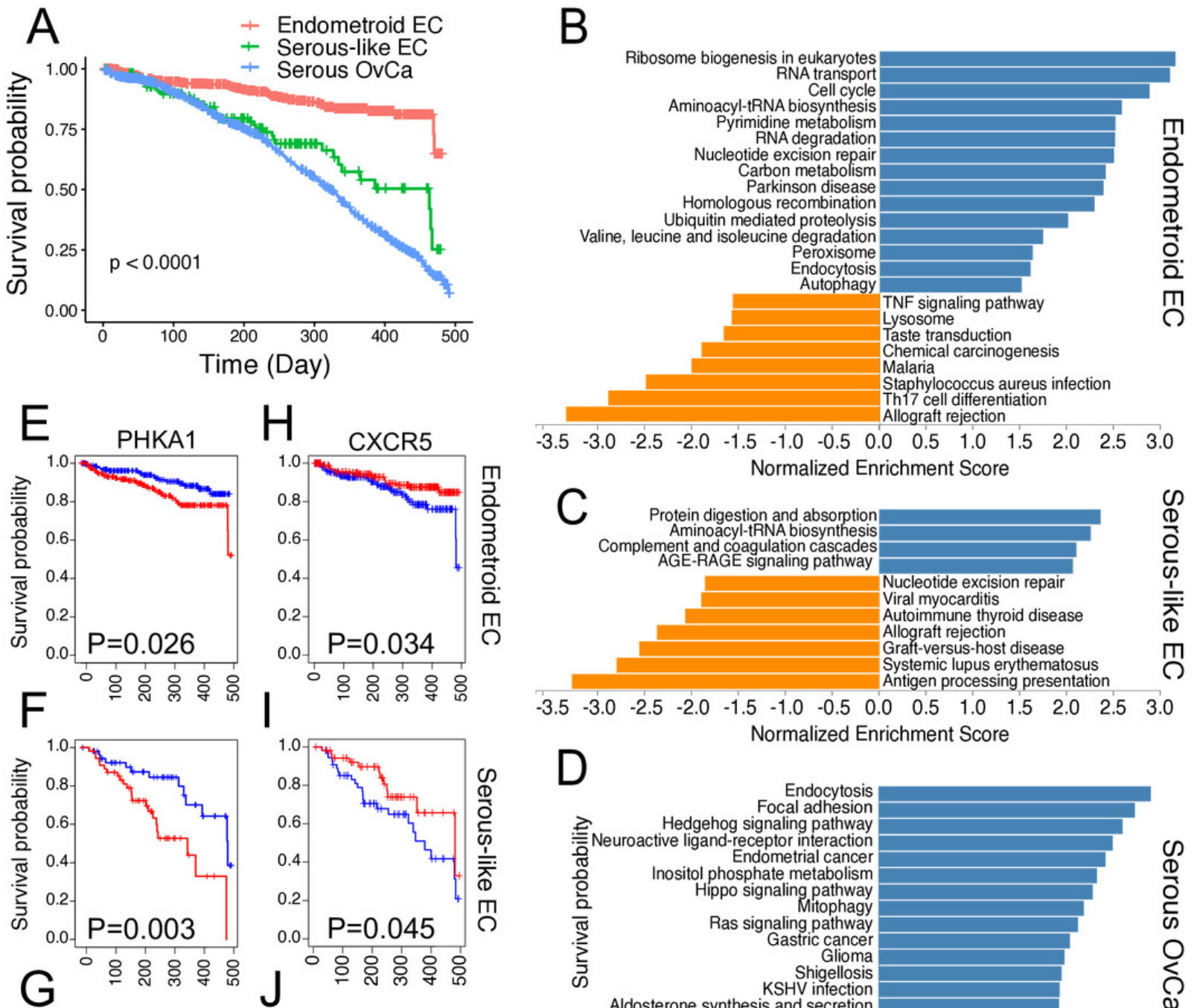

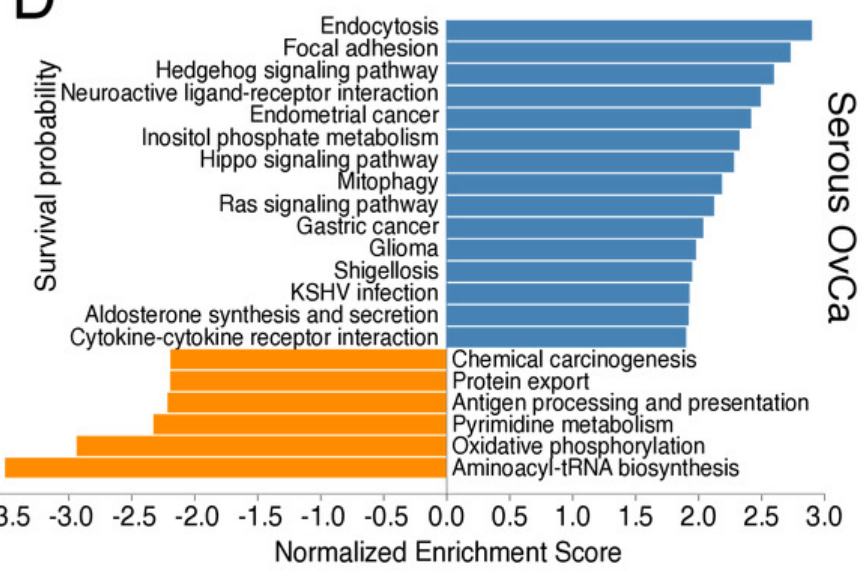

Favorable prognostic

Adverse prognostic

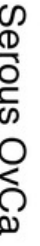

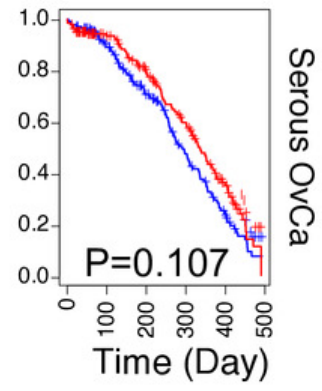

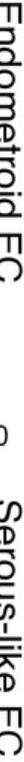
.

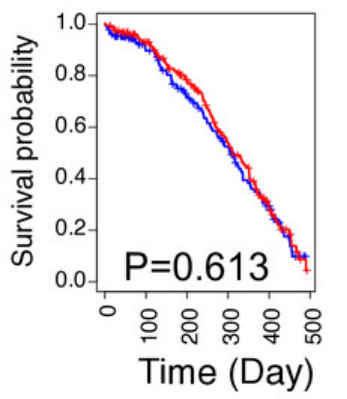

Expression levels:

- High

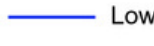




\section{Figure 5}

Immune infiltration for the three cancer types

(A-B) Boxplots comparing the overall immune infiltration (A) and stromal infiltration (B) of these three cancer types. Results were calculated using ESTIMATE. P values were calculated by student's t-test. (C) Boxplots comparing interested immune cell abundances, including CD8 T cell, Macrophage, Monocyte, NK cell and Treg Cell. Results were calculated using CIBERSORT. *: adjusted $\mathrm{p}$ value $<0.05 ; *$ : adjusted $\mathrm{p}$ value $<0.01$. $\mathrm{P}$ values were resulted from Student's t-test (D-F) Kaplan-Meier curves comparing the prognostic values of CD8 T cell in endometroid EC (D), serous-like EC (E) and serous OvCa (F). P values were calculated by log-rank test. 

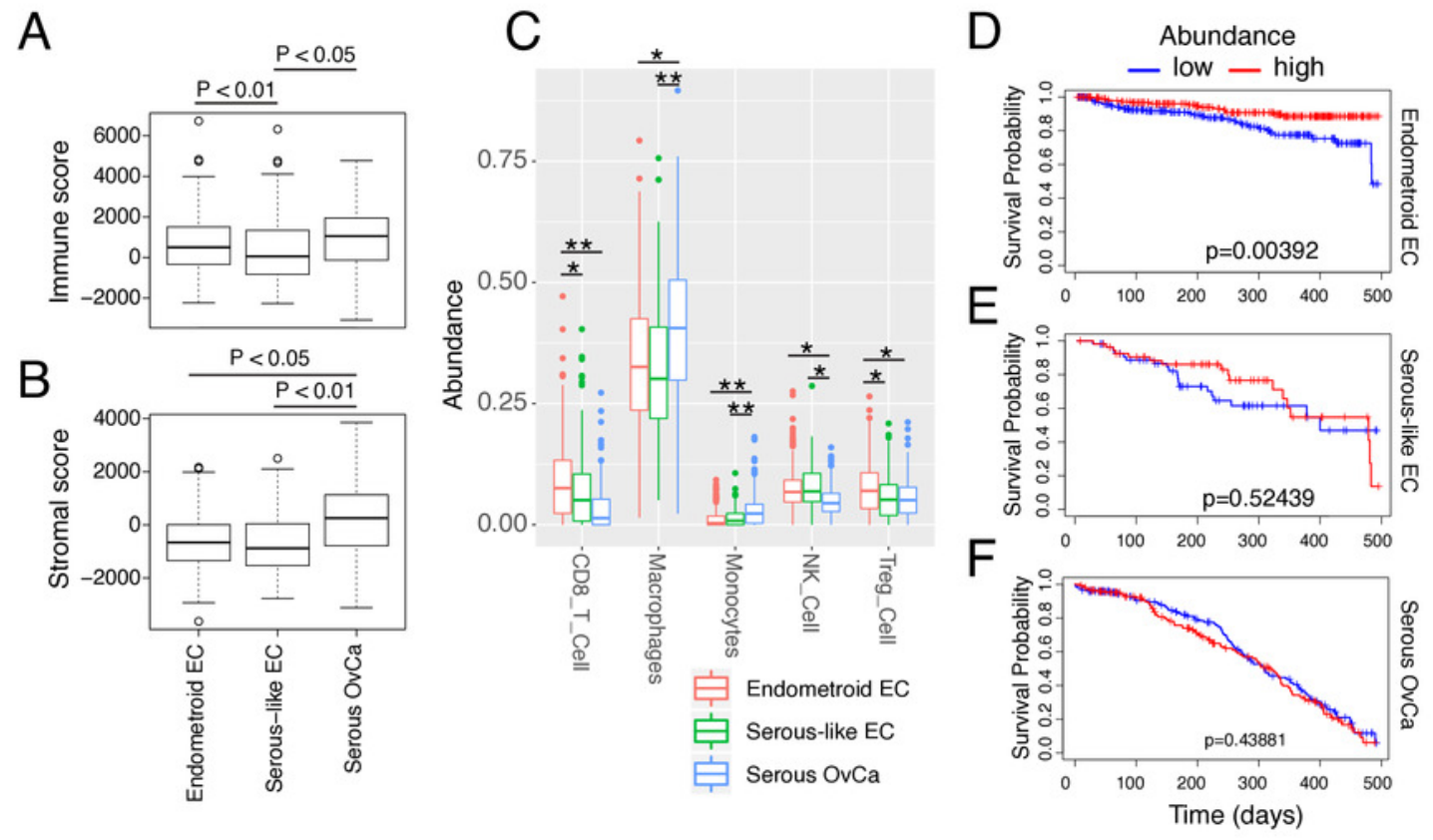


\section{Table $\mathbf{1}$ (on next page)}

The sample size $(\mathrm{N})$ for each omics data type

Numbers in parentheses indicate the overlap of each omics data size with the clinical data. 
1

\begin{tabular}{|l|l|l|l|}
\hline \multicolumn{1}{|c|}{ Cancer types } & Endometroid EC & Serous-like EC & Serous OvCa \\
\hline Clinical Data & $\mathrm{N}=411$ & $\mathrm{~N}=115$ & $\mathrm{~N}=587$ \\
\hline RNA expression & $\mathrm{N}=409(409)$ & $\mathrm{N}=114(114)$ & $\mathrm{N}=308(303)$ \\
\hline $\begin{array}{l}\text { Somatic copy } \\
\text { number Alternation }\end{array}$ & $\mathrm{N}=391(391)$ & $\mathrm{N}=110(110)$ & $\mathrm{N}=436(436)$ \\
\hline Somatic mutation & $\mathrm{N}=293(293)$ & $\mathrm{N}=65(52)$ & $\mathrm{N}=549(538)$ \\
\hline
\end{tabular}

2

3 


\section{Table 2 (on next page)}

Summarization of all the molecular genotype and phenotype comparisons

For each molecular event, one or two representative features are shown. The last column of the table indicates the pair of cancer types that is most similar than any other pairs, see the discussion session for more details. 
1

\begin{tabular}{|c|c|c|c|c|}
\hline $\begin{array}{l}\text { Molecular } \\
\text { events }\end{array}$ & $\begin{array}{c}\text { Endometrioid } \\
\text { EC }\end{array}$ & $\begin{array}{l}\text { Serous-like } \\
\text { EC }\end{array}$ & Serous OvCa & Similar pair \\
\hline $\begin{array}{l}\text { Copy number } \\
\text { alternation }\end{array}$ & $\begin{array}{l}\text { Weak } \\
\text { (1q gain) }\end{array}$ & $\begin{array}{c}\text { Strong } \\
\text { (Multiple } \\
\text { SCNA arms) }\end{array}$ & $\begin{array}{c}\text { Strong } \\
\text { (Multiple } \\
\text { SCNA arms) }\end{array}$ & $\begin{array}{l}\text { Serous-like } \\
\text { EC and } \\
\text { Serous OvCa }\end{array}$ \\
\hline Somatic mutation & $\begin{array}{l}\text { High (Lead } \\
\text { by non-TP53 } \\
\text { genes) }\end{array}$ & $\begin{array}{c}\text { Low (Lead by } \\
\text { TP53) }\end{array}$ & $\begin{array}{c}\text { Low (Lead by } \\
\text { TP53) }\end{array}$ & $\begin{array}{l}\text { Serous-like } \\
\text { EC and } \\
\text { Serous OvCa }\end{array}$ \\
\hline $\begin{array}{l}\text { Overall gene } \\
\text { expression and } \\
\text { pathway activity }\end{array}$ & $\begin{array}{l}\text { Inflammation } \\
\text { low and } \\
\text { metabolic } \\
\text { high }\end{array}$ & $\begin{array}{l}\text { Inflammation } \\
\text { low and } \\
\text { metabolic low }\end{array}$ & $\begin{array}{l}\text { Inflammation } \\
\text { high and } \\
\text { metabolic low }\end{array}$ & None \\
\hline Survival signatures & $\begin{array}{l}\text { Aminoacyl- } \\
\text { RNA } \\
\text { biosynthesis } \\
\text { (good) }\end{array}$ & $\begin{array}{l}\text { Aminoacyl- } \\
\text { RNA } \\
\text { biosynthesis } \\
\text { (good) }\end{array}$ & $\begin{array}{l}\text { Aminoacyl- } \\
\text { RNA } \\
\text { biosynthesis } \\
\text { (bad) }\end{array}$ & $\begin{array}{l}\text { Serous-like } \\
\text { EC and } \\
\text { Endometroid } \\
\text { EC }\end{array}$ \\
\hline $\begin{array}{l}\text { Immune infiltration } \\
\text { profiles }\end{array}$ & $\begin{array}{c}\text { High } \\
\text { (cytotoxic) }\end{array}$ & Low & $\begin{array}{c}\text { High } \\
\text { (macrophage } \\
\text { and monocyte) }\end{array}$ & None \\
\hline
\end{tabular}

